\title{
The Mechanism of Placebo?
}

Placebo responses and factors influencing the results of randomized clinical trials are frequently discussed but rarely investigated empirically. The article of Kiene and Kienle in this issue questions in a provocative way a number of common assumptions and 'results' on placebo. In the Journal Club we summarize and discuss three relevant empirical studies investigating the 'mechanism of action' of placebos, the variability of placebo group response rates in randomized trials of cimetidine in ulcer disease, and the influence of informed consent on study results.

Levine JD, Gordon NC, Fields HL: The mechanism of placebo analgesia. Lancet 1978; ii:654657.

Objective: To investigate the hypothesis that endorphins mediate placebo analgesia.

Design: Randomised, double-blind, placebo-controlled trial. Patients: 27 male and 24 female otherwise healthy persons with impacted wisdom teeth.

Interventions: 17 patients received placebo both 2 and $3 \mathrm{~h}$ after nitrous oxide anesthesia for surgery; 23 patients received placebo after $2 \mathrm{~h}$ and an opiate antagonist (naloxone) after $3 \mathrm{~h} ; 11$ patients received naloxone after $2 \mathrm{~h}$ and placebo after $3 \mathrm{~h}$. Outcome Measures: Pain was measured 9 times (immediately after anesthesia, after $1 \mathrm{~h}$, before and after application of naloxone or placebo at 2 and $3 \mathrm{~h}$ as well as after 2.5, 3.5 and $4 \mathrm{~h}$ ) using a visual analogue scale (VAS) and by an assessment of the change of pain intensity compared to the last pain rating. Results: 5 patients dropped from the study after having completed 8 of 9 pain ratings. Throughout the measurement period, there was a rise in the mean pain level reported. Patients given naloxone reported sigificantly greater pain than those given a placebo. Patients given a placebo as their first drug were classified as placebo-responders when pain was reduced or unchanged after first application, or non-responders if pain increased. Naloxone given as a $2 \mathrm{nd}$ drug produced no additional increase in pain levels of non-responders but did increase pain levels of placebo-responders. Non-responders had a final mean pain rating identical to that of responders who received naloxone as their 2 nd drug.

Conclusions: The enhancement of reported pain produced by naloxone can be entirely accounted for its effect on placebo responders. These data are consistent with the hypothesis that endorphin release mediates placebo analgesia for dental postoperative pain.

Commentary - G. ter Riet, A.G.H. Kessels, P. Leffers; Maastricht

In 1978 Levine et al. apparently believed that placebo effects exist. As with many other effects, the placebo effect calls for an explanation on the molecular level. Surprisingly, however, Levine et al. quote previous studies on placebo effects (in analgesia) in a naive way. For example, Beecher's paper 'The powerful placebo' [1] and Park and Covi's 'Nonblind placebo trial' [2] do not contain sound evidence of placebo effects. Recently, Kienle shed doubt on the existence of placebo effects altogether [3]. If she is right, there is no effect that needs to be explained. Let us discuss why, in our opinion, the paper by Levine et al. does not elucidate the mechanism of placebo analgesia. We warn the reader of this commentary in advance that there is no easy way to understand the paper that we discuss here. Detailed study of at least the figures 1,2 and 3 (of the original paper) would seem necessary. 
Major Points:Most points we raise were made before [4-6]. Note that no use was made of a non-treatment control group. However, to prove that the placebo administration had an effect on the pain levels, the use of a non-treatment group is necessary. We cannot exclude that the solid line in their figure 1 reflects (only) the natural course of postoperative pain and the broken line, after drug 2, a pain-enhancing effect by naloxone, either by reducing the nitrous oxide anesthesia or by an interaction with the opiate receptors. Any doubts about whether a placebo effect was established at all makes everything that follows about alleged mechanisms speculative. In fact, we could end the discussion at this point. However, the topic is important enough to justify some more criticism.

Levine et al, drew their main conclusions from results of a (sub)group of 23 patients all of whom received a placebo as drug 1 and naloxone as drug 2 (see fig. 3 and the broken line in fig. 1.). Note that within this (sub)group there is no experimental contrast of interventions. This (sub)group was then sub-

\section{KAKGER}

(C) 1996 S. Karger GmbH, Freiburg Fax (0761) 4520714

$7-$

$6-$

$05->$

$0)$

$\sigma \hat{u}-3-$

\section{II t i iy-}

$\mathrm{J} \psi \mathrm{T}$

|I

2-1-

//X

* X

I I

IS I

1 |S

$\Phi>$

$\mathrm{c}$

o Û

$30 \mathrm{mla}$

TIME
$\beta)$
ç $\sigma \alpha$
$0)$ 
Fig. 1. The effect of naloxone on pain. Time was measured from the start of anaesthesia. Both patient groups were given placebo as their first drug. The administration of the secound drug is denoted by D2. $\cdot$ mean ( \pm s.e.) pain ratings for patients given placebo as a second drug $(n=17)$; $\mathrm{O}$ mean pain ratings for patients given $10 \mathrm{mg}$ naloxone as a second drug $(\mathrm{n}=23)$. Difference during the three immediately postoperative hours was insignificant. The group given nolxone had signiíicanly greater mean pain ratings $1 \mathrm{~h}$ its administration ( $\mathrm{p}>0.05$ by $\mathrm{t}$ test).

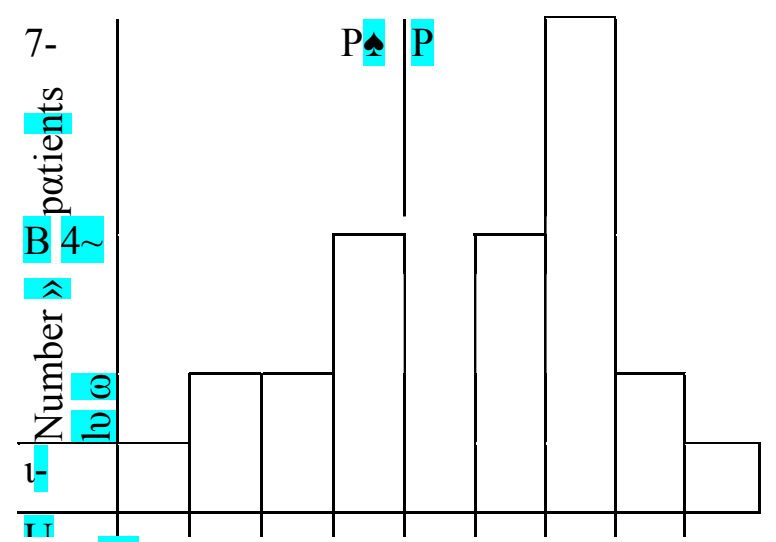

$-3-2-10123$ Change in pain rating

Fig. 2. Change in pain $1 \mathrm{~h}$ after placebo compared with pain rating $5 \mathrm{~min}$ before placebo. $\mathrm{P}+$ and $\mathrm{P}$ - indicate the placebo responders and non-responders, respectively. A bimodal distribution is apparent.

divided into 2 groups of 9 ( $\mathrm{P}+$ in fig. 2) and 14 patients (P- in fig. 2) based on an (arbitrary) cutpoint for 'placebo reactivity'. Had the 17 patients who received placebo both as D1 and D2 (solid line in fig. 1) been subdivided in the same way we might have been able to see what part of 'the effect' was caused by regression to the mean and what part was caused by a greater TIME

Fig. 3. Differential effect of naloxone on placebo responders and nonre-sponders. All patients received placebo as the first drug and naloxone as the second. Upper graph: mean pain levels for placebo responders $(\bullet)(n=9)$ and nonresponders $(O)(n=14)$ are plotted. After naloxone, the difference in mean pain level for these two groups becomes insignificant. Lower graph: cumulative change in pain level compared with 5 min before the drug was given (data from upper curve). After naloxone the change in pain level is greater in positive placebo responders. A significant difference is apparent 5 min after naloxone ( $p>0.05$ by t test), and is greater 20 and $60 \mathrm{~min}$ after naloxone $(\mathrm{p}>0.125)$. The latency of the placebo effect seems to be less than $5 \mathrm{~min}$. pain-intensifying effect of naloxone in those patients who felt less pain after Dl. After all, if you feel severe pain already, your pain is less likely to increase much than if you feel little pain initially.

The authors report 4 dropouts in the $n=23$ group (D2 = naloxone). These occurred in the 40 minute time interval before the last pain measurement only. Instead of 9 pain measurements these patients had 8 and these 8 pain scores could (and should) have been used in the calculation of the first 8 mean pain scores. The stability of the last mean pain score (4 measurements missing) could have been assessed by a sensitivity analysis, i. e., by substituting a plausible range of pain scores for these dropouts to see how different plausible values effect the end result.

Journal Club 
Forsch Komplementärmed 1996;3:158-164 159

Minor Points: A 'treatment' contrast was established only at time point D2 (fig. 1). Before the time point D2 the groups are on the same 'treatment'. There is a sharp rise in pain level just after placebo was given for the first time in the group that received placebo on both occasions (solid line, $\mathrm{N}=\Gamma 7$ ) with virtually no rise in the other group (broken line). This raises questions about double-blind conditions although chance and the 4 patients who dropped out may also provide explanations. The unequal group sizes of 27,18,11 and the unknown number of patients on morphine raise questions about the treatment allocation procedure which was not described properly. Randomization with envelopes is not fool-proof. Levine et al.'s assertion that a bimodal distribution is apparent in figure 2 is incorrect. There is one mode at the value 2.5. Conclusion. It is not clear whether a placebo effect was produced in this study. A greater painintensifying effect by naloxone in patients with low pain levels (after Dl) combined with regression to the mean may explain these data just as well as the proposed endorphin-releasing effect of a placebo.

References

Beecher HK: The powerful placebo. JAMA 1955;159:1602-1606.

Park LC, Covi L: Nonblind placebo trial: An exploration of neurotic outpatients' response to placebo when its inert content is disclosed. Arch Gen Psychiatry 1965;12:336-345.

Kienle GS: Der sogenannte Placeboeffekt: Illusion, Fakten, Realität. Stuttgart, Schattauer, 1995. Goldstein A, Grevert P: Placebo analgesia, endorphins, and naloxone (Letter). Lancet 1978; $2: 1385$.

Korczyn AD. Mechanism of placebo analgesia (Letter). Lancet 1978;2: 1304-5. Skrabanek P. Naloxone and placebo (Letter). Lancet 1978;2:791.

Address: G. ter Riet, MD, PhD, Department of Epidemiology, University of Limburg, P.O. Box 616, 6200 MD Maastricht, The Netherlands.

Variability of Placebo Group Response Rates and Correlation with Between-Group Differences Moerman DE: General medical effectiveness and human biology: Placebo effects in the treatment of ulcer disease. Med Anthropol Q 1983;14:13-16.

Objective: To investigate the variability of response rates in placebo groups and their impact on study results in placebo-controlled trials of cimetidine in ulcer disease. Design: Meta-analysis. Data Sources: Eligible trials were searched in Medline (search term cimetidine) from 1977 to 1980.

Study Selection: 31 randomized placebo-controlled trials of cimetidine including 1692 patients with gastric or duodenal ulcers.

Main Outcome Measure: Endoscopically verified 'healing rates' after 4 to 6 weeks of treatment in treatment and placebo groups. Results: Overall 'healing rates' were $76 \%$ for patients treated with cimetidine and $48 \%$ among patients treated with a placebo. 13 studies demonstrated statistically significant differences between drug and placebo groups. Healing rates in placebo groups varied between 10 and $90 \%$. While healing rates in drug groups did not differ between trials with significant and nonsignificant results ( $75 \mathrm{vs.} 77 \%$ ), healing rates in the placebo groups of trials with significant results were lower than those of trials with nonsignificant results $(37 \mathrm{vs}$. $58 \% ; \mathrm{t}=2.46, \mathrm{p}=0.013)$. A regression analysis demonstrated a significant relationship between control group healing rate and experimental group healing rate $(\mathrm{r}=0.56)$. The 6 German studies in the sample show a significantly higher placebo improvement rate than the 25 other studies (63 vs. $41 \%, \mathrm{t}=2.85, \mathrm{p}<0.01)$. 
Conclusions: The large variability in placebo group response rates among the studies reviewed is unlikely to be caused by chance alone and cannot be ignored. The size of the control group response rate was significantly correlated with the size of the between-group differences. Kommentar - K. Jonasch, Heidelberg Es gab Zeiten, in denen es einfacher war, Sachverhalte einer Überprüfung zu unterziehen. D. E. Moermans Artikel «Placebo Effects in the Treatment of Ulcer Disease» gehört dazu. In dieser kurzen und überaus geistreichen Meta-Analyse zitiert er 31 placebokontrollierte Studien zur Behandlung von Magen-Darm-Ulzera, die er Medline von Januar 1977 bis März 1980 unter dem Stichwort Cimetidin entnehmen konnte. Versuchen wir heute dasselbe unter dem Stichwort «ulcera-cimetidine-placebo» zu wiederholen, bekommen wir in den letzten drei Jahren keine einzige verwertbare Arbeit. 1st das Ulkus also ausgestorben? Natürlich keineswegs, sondern die Ätiologie hat radikal gewechselt. Es ist eine Infektionskrankheit geworden, hervorgerufen durch den Keim Helicobacterpyloris (HP), dem man durch eine Kombination von Säurehemmern darunter auch das gute alte Cimetidin - und Antibiotika Herr zu werden versucht. Also müssten hier unter diesem Stichwort in Medline die vermissten placebokontrollierten Studien sein. Auch ge-fehlt. Es gibt keine randomisierten Studien zum Thema Ulkus mehr, in denen das «reine» Placebo allein vorkommt. Es werden unterschiedliche Antibiotika immer zusammen mit anderen Medikamenten (z. B. Säurehemmer) gegeneinander getestet, diese auch teils durch Placebos ausgetauscht - aber nur Placebo, solche Studien finden nicht mehr statt. Ein «Verum-Mittel», wie z.B. eben Cimetidin, wird wenigstens immer gegeben. Hier ist also nicht das Ulkus, sondern der reine Placebo-Effekt ausgestorben. Wenn er früher zwischen 10 und 90\% zur Heilung beitrug, dann ist heute die Kombinationstherapie zur Eradika-tion des HP so effektiv, dass an das alleinige Placebo überhaupt nicht mehr gedacht wird. Allenfalls bei Non-Ulcus-Dyspepsien finden noch Versuche statt, aber man weiss, dass keine Be-

160 Forsch Komplementärmed 1996;3:158-164

Journal Club 